\title{
The Distribution of la Antigens of the H-2 Complex on Lymph Node Cells by Immunoferritin Labelling
}

\author{
Jane S. Schultz, Jeffrey A. Frelinger, Sun-Kee Kim, \\ and Donald C. Shrfffit.f. \\ Veterans Administration Hospital, Ann Arbor, Michigan, and Departments of Human Genetics \\ and Anatomy, University of Michigan, Ann Arbor, Michigan
}

Received June 28, 1974

\begin{abstract}
The distribution of Ia antigens on the surfaces of lymph node lymphocytes of several mouse strains was investigated using indirect immunoferritin labeling and electron microscopy. The immunoferritin labeling results agreed with results of cytotoxic tests in strain distribution of reactivity, proportion of cells showing label, and cell populations reacting. Capping was induced by increased incubation temperature but conditions for Ia antigen mobilization varied somewhat between the two anti-Ia antisera employed. Uncapped specimens generally showed a denser, more evenly distributed antigen coating than is the case for $\mathrm{H}-2$ antigens labeled by the same indirect immunoferritin method.
\end{abstract}

\section{INTRODUCTION}

The major histocompatibility (H-2) antigens of the mouse have been shown to have wide tissue distribution, being present on all lymph node lymphocytes as determined by cytotoxic assay (1), immunoferritin labeling and electron microscopy (2), and also labeling with fluorescent conjugated antibodies (3). Most reports place these antigens on restricted areas of the cell surface, i.e., in patches (4). However, the conditions of incubation of the cells either with marker-conjugated anti-H-2 serum or with unlabeled anti-H-2 serum followed by conjugated antimouse immunoglobulin serum influence this distribution $(5,6)$. It has been shown that the attachment of either antibodies or lectins modifies the topological expression of cell membrane components (7). Patching and capping of surface immunoglobulin molecules mediated by anti-immunoglobulin serum occur readily at $37^{\circ} \mathrm{C}$, but these actions of heterologous anti-immunoglobulin have also been reported to occur even at $0^{\circ} \mathrm{C}(8)$. Pinocytosis of antibodies has also been noted as evidenced by internalization of the labeled antibody seen in the electron microscope (8).

Recently, a new lymphocyte antigen system (Ia) has been described in mice (912). These antigens, present on lymph node cells as well as other lymphatic tissues, are controlled by genes in the $I$ (immune response) region of the mouse $\mathrm{H}-2$ complex, which maps between the $H-2 K$ and $H-2 D$ loci. These antigens were originally termed Lna (lymph node) antigens but are now referred to as Ia antigens (13). The $\mathrm{H}-2$ antigens studied in the earlier reports are those controlled by the $H-2 D$ and $H-2 \mathrm{~K}$ inci; however, many $\mathrm{H}-2$ antisera have now been shown to 
be contaminated with anti-Ia antibodies (14). Almost certainly, therefore, many of these studies have used antisera that contained a mixture of anti-H-2 and anti-Ia antibodies. Thus, in view of the fact that these cell surface antigens are closely related genetically and both are expressed on lymphocytes, it is important to determine the labeling characteristics of Ia antigens for comparison with $\mathrm{H}-2$ antigens.

Specific alloimmune antisera against Ia antigens can be prepared by reciprocal immunization of A.TH and A.TL congenic inbred strains of mice which are identical in $\mathrm{H}-2 \mathrm{~K}$ and $\mathrm{H}-2 \mathrm{D}$ regions but differ in the $I$ and $S$ regions. These antisera, unlike anti-H-2 sera, react only with a subpopulation of lymphoid cells in the cytotoxic assay employed for their detection. The percentage of cells reacting varies with the lymphoid organ and the methodological details of the cytotoxic test. For lymph node lymphocytes the percentage of cells lysed by the appropriate antiserum is a maximum of $70 \%$ (15).

It is necessary to determine the reactions of cells with anti-Ia sera by additional methods to confirm the original serologic and chemical evidence that Ta antigens are, in fact, distinct from $\mathrm{H}-2$ (16). It is further necessary to determine the proportion of Ia positive cells by a method which does not require the interaction of antibody and complement so that the possibility of interference by a large number of noncomplement fixing antibody molecules in the anti-Ia sera can be eliminated. The two-stage reaction of the cells with the alloantisera followed by ferritin-labeled rabbit anti-mouse IgG meets this requirement.

The purpose of this study was to investigate the behavior of Ia antigens on the cell surface of mouse lymph node lymphocytes under various cxperimental conditions by immunoferritin electron microscopy. Information obtained by this technique would also reveal morphological characteristics of cell surfaces unobtainable by other methods. It would be possible also to determine whether reaction with antiIa sera is restricted to cells with certain recognizable morphological characteristics.

\section{MATERIALS AND METHODS}

\section{Mice}

All mice were raised in the mouse colony in the University of Michigan, Department of Human Genetics. Strains employed in these experiments together with their $H-2$ haplotypes and Ia specificities are shown in Table 2.

\section{Antisera}

Ferritin-labeled rabbit anti-mouse IgG was obtained from Cappel Laboratories, Downington, PA. Anti-H-2 sera were prepared according to the immunization schedules previously described (17). Anti-H-2.4 is (AKR.M $\times$ B10) $F_{1}$ antiB10.A; anti-H-2.1 is (C3H.Q $\times$ B10.D2) F 1 anti-C3H.R3. Anti-Ia antisera were prepared by reciprocal immunizations of A.TH $\left(H-2^{\text {t2 }}\right)$ and A.TL $\left(H-2^{\text {t1 }}\right)$ mice which differ only in the I region of the $H-2$ complex (9). Thymus and lymph nodes were the immunizing tissues.

\section{Cell Labeling}

Twenty microliters of an appropriate antiserum was added to a washed, FicollIsopaque-purified, lymph node cell button $\left(5 \times 10^{6}\right.$ cells $)$, along with $50 \mu$ l of 
cold l'Bs. The cells were resuspender in the test serum and shaken gently for 20 min at 4 or $37^{\circ} \mathrm{C}$. The cells were then washed four times at $4^{\circ} \mathrm{C}$ in cold PBS by centrifugation at $800 \mathrm{~g}$. Fifty microliters of PBS and $5 \mu$ of ferritin-labeled rabbit anti-mouse IgG were then added to the cell button, the cells resuspended and shaken gently for 20 or $30 \mathrm{~min}$ at 37 or $4^{\circ} \mathrm{C}$. The wash step was repeated with a final centrifugation at $1500 \%$.

\section{Electron Microscopy}

Washed. labeled cells were fixed for 15 min at $4^{\circ} \mathrm{C}$ in $1 \%$ paraformaldelinde$1 .+\%$ glutaraldehyde in $0.1 \mathrm{M}$ sodium cacodylate buffer (18). The cell button was then washed and stored overnight in sodium cacolylate buffer in the refrigerator. 'l he cells were post fixed in $1 \%$ osmium tetroxide in sodium cacodylate buffer for 1 hr, dehydrated with increasing concentrations of ethanol followed by propylene oxide and embedded in Epon. Thin sections were cut on a MT IIB Porter-Blum microtome, stained with uranyl acetate and lead citrate, and studied in a Hitachi 11c electron microscope.

\section{Cell Separation}

T cells were prepared by passage through nylon wool columns using the methorl of Julius ot al. (19). B cells were obtained by vigorous agitation of the columns after elution of the $\mathrm{T}$ cells. These $\mathrm{B}$ cells are contaminated with significant numbers (about $20 \%$ ) of $\mathrm{T}$ cells, as judged by reactivity with anti-Thy-1.2 serum.

\section{Absorptions}

One hundred microliters of A.TH anti-A.TI, serum were absorbed twice with either $5 \times 10^{-}$A.TH or A.TL spleen cells each time. Absorptions were carried out at $0^{\circ} \mathrm{C}$ for $30 \mathrm{~min}$.

\section{RESULTS}

A summary of preliminary experiments is found in Table 1 . We examined the specificity of the rabbit anti-mouse IgG as follows: Lymph node cells were labeled with anti-H-2 antisera of the appropriate specificity followed by ferritin-conjugated rabbit anti-mouse $\operatorname{IgG}$. Samples of lymph node cells from B10.D2 mice, which are known to carry the $H_{2}-I$ specificity $\mathrm{H}-2.4$ and lack $\mathrm{H}-2.1$, where incubated with anti-H-2.4. anti-H-2.1, pooled normal mouse serum, or phosphate-huffered saline, followed by ferritin-labeled anti-mouse $\operatorname{IgG}$. Except for the cells which had been incubated with anti-H-2.4, these samples showed little evidence of ferritin labeling. These initial experiments were performed with all incubation at $37^{\circ} \mathrm{C}$, and considerable clumping of ferritin particles was noted on positive cells. A small number of cells in this sample exhibited aggregation at one pole (capping). The ferritin-labeled rabbit anti-mouse IgG was not absorbed to cell surfaces nonspecifically and did not label cell surface IgM immunoglobulins. These experiments established the specificity of the commercial serum preparation sufficiently to validate its use in the cletermination of reaction of anti-Ia with cell surfaces without further absorption. It is important to note the lack of background labeling which would have been expecter 


\section{TABLE 1}

Preliminary Exferiments for Determination of Optimal CONDITIONS OF InCUBATION

\begin{tabular}{|c|c|c|c|c|}
\hline \multirow[t]{2}{*}{$\begin{array}{c}\text { First } \\
\text { incubation } \\
\text { serum }\end{array}$} & \multirow[t]{2}{*}{$\begin{array}{l}\text { Cell } \\
\text { type }\end{array}$} & \multicolumn{2}{|c|}{$\begin{array}{l}\text { Incubation } \\
\text { temperature } \\
\left({ }^{\circ} \mathrm{C}\right)\end{array}$} & \multirow[t]{2}{*}{ Results } \\
\hline & & I & $\mathrm{II}^{a}$ & \\
\hline $\mathrm{PNS}^{b}$ & B10.D2 & 37 & 37 & $\begin{array}{l}\text { No surface label, sparse } \\
\text { intracellular label }\end{array}$ \\
\hline Anti-H-2.4 & B10.D2 & 37 & 37 & $\begin{array}{l}\text { Dense label with capping } \\
\text { and/or patching }\end{array}$ \\
\hline Anti-H-2.1 & B10.D2 & 37 & 37 & $\begin{array}{l}\text { Few scattered ferritin } \\
\text { molecules }\end{array}$ \\
\hline $\mathrm{PBS}^{c}$ & B10.D2 & 37 & 37 & No labeling \\
\hline Anti-H-2.4 & B10.D2 & 4 & 4 & Sparse label, some patching \\
\hline Anti-H-2.1 & B10.D2 & 4 & 4 & Unlabeled \\
\hline Anti-H-2.4 & B10.D2 & 4 & 37 & Dense uniform labeling \\
\hline Anti-H-2.1 & $\mathrm{B} 10 . \mathrm{D} 2$ & 4 & 37 & No label \\
\hline Anti-H-2.4 & B10.D2 & 37 & 4 & Sparse label, some patching \\
\hline
\end{tabular}

${ }^{a}$ Serum for second incubation in each case was rabbit anti-mouse IgG.

${ }^{b} \mathrm{PNS}=$ pooled normal serum (mouse).

c $\mathrm{PBS}=$ phosphate-buffered saline.

if the anti-IgG were contaminated with either significant anti-light chain or anti- $\mu$ chain antibodies.

Since it was desirable for these experiments to limit capping and accompanying pinocytosis as much as possible, we ascertained the conditions which gave the maximum labeling and the most even distribution of labels, using the anti-H-2.4 B10.D2 combination previously described. Incubation with anti-H-2 at $4{ }^{\circ} \mathrm{C}$ followed by incubation with anti-IgG at $37^{\circ} \mathrm{C}$ provided the most uniform and most dense labeling. Both $4^{\circ} \mathrm{C}-4^{\circ} \mathrm{C}$ and $37^{\circ} \mathrm{C}-4^{\circ} \mathrm{C}$ incubations gave very light, scattered labeling.

The results of experiments using anti-Ia antisera are shown in Table 2. The lymph node cell preparation consisted mostly of identifiable lymphocytes. Occasionally, polymorphonuclear leucocytes and some cells which could not be identified definitively as lymphocytes were present. However, these cells in no case revealed any label and, therefore, were excluded from the cell counts. In the first experiment, A.TH anti-A.TL serum which contains Ia specificities $1,2,3$, and 7 was employed as test antiserum with A.TL cells as the target cells. Approximately $60 \%$ of the cells revealed label distributed very uniformly and heavily over the entire cell surface (see Fig. 1). Control cells (those which did not react with A.TH anti-A.TL in the cytotoxic assay as well as cells incubated with phosphate-buffered saline in the initial incubation) showed negligible labeling. One sample of A.TH normal serum tested with A.TL cells showed sparse nonuniform label on $20 \%$ of the cells (see Fig. 2). A low level of cytotoxicity has also been observed with other isolated bleedings of A.TH normal serum. 
TABL,E 2

SUMMART OF EXPERIMENTAL RESULTS

\begin{tabular}{|c|c|c|c|c|}
\hline Anti-Ia serum & $\begin{array}{c}\text { Target cell } \\
\text { type }\end{array}$ & $\begin{array}{c}\mathrm{Ia}^{a} \\
\text { specificities } \\
\text { and } \mathrm{H}-2 \\
\text { haplotypes }\end{array}$ & Special conditions & Results \\
\hline $\begin{array}{l}\text { A.TH anti-A.TL } \\
\text { anti-la } 1,2,3,7\end{array}$ & A.TL LN ${ }^{b}$ & $\begin{array}{l}1,2,3,7 \\
\text { ti }\end{array}$ & Vone & $\begin{array}{l}\text { 60-80\% of cells heavily } \\
\text { and uniformly } \\
\text { labeled }\end{array}$ \\
\hline $\begin{array}{l}\text { A.TH anti-A.TL } \\
\text { anti-Ia } 1,2,3,7\end{array}$ & A.TH LN & $\begin{array}{l}4,5,9 \\
\mathrm{t} 2\end{array}$ & Vone & No label \\
\hline $\begin{array}{l}\text { A.TH anti-A.TL } \\
\text { anti-la } 1,2,3,7\end{array}$ & AKR.M LN & $\begin{array}{l}1,2,3,7 \\
\mathrm{~m}\end{array}$ & None & $\begin{array}{l}\text { About } 50 \% \text { patchy } \\
\text { label }\end{array}$ \\
\hline $\begin{array}{l}\text { A.TH anti-A.TL } \\
\text { anti-la } 1,2,3,7\end{array}$ & B10.K LN & $\begin{array}{l}1,2,3,7 \\
\mathrm{k}\end{array}$ & None & $\begin{array}{l}60-80 \% \text { heavily } \\
\text { labeled }\end{array}$ \\
\hline $\begin{array}{l}\text { A.TH anti-A.TL } \\
\text { anti-Ia } 1,2,3,7\end{array}$ & B10.S LN & $\begin{array}{l}4,5,9 \\
\mathrm{~s}\end{array}$ & None & No label \\
\hline $\begin{array}{l}\text { A.TH anti-A.TL } \\
\text { anti-la } 1,2,3,7\end{array}$ & B10.D2 L.N & $\begin{array}{l}6,7,8 \\
d\end{array}$ & None & $20-30 \%$ lightly labeled \\
\hline $\begin{array}{l}\text { A.TH anti-A.TL. } \\
\text { anti-Ia } 1,2,3,7\end{array}$ & A.TL I,N & $\begin{array}{l}1,2,3,7 \\
\mathrm{t} 1\end{array}$ & $\begin{array}{l}\text { Sera absorbed with } \\
\text { A.TL spleen }\end{array}$ & $\begin{array}{l}\text { Light label on about } \\
20 \% \text { of cells }\end{array}$ \\
\hline $\begin{array}{l}\text { A.TII anti-A.TI } \\
\text { anti-Iat } 1,2,3,7\end{array}$ & A.TI, LN & $\begin{array}{l}1,2,3,7 \\
\text { t1 }\end{array}$ & $\begin{array}{l}\text { Sera absorbed with } \\
\text { A.TH spleen }\end{array}$ & $\begin{array}{l}\text { About } 50 \% \text { of cells } \\
\text { heavy, uniform } \\
\text { labeling }\end{array}$ \\
\hline $\begin{array}{l}\text { A.TH anti-A.TL } \\
\text { anti-Ia } 1,2,3,7\end{array}$ & A.TL T & $\begin{array}{l}1,2,3,7(?) \\
\mathrm{t} 1(?)\end{array}$ & $\begin{array}{l}\text { T cells (nonadherent to } \\
\text { nylon wool) }\end{array}$ & No label \\
\hline $\begin{array}{l}\text { A.TH anti-A.TL } \\
\text { anti- } \mathrm{Ia} 1,2,3,7\end{array}$ & A.TL B & $\begin{array}{l}1,2,3,7(?) \\
\mathrm{t} 1(?)\end{array}$ & $\begin{array}{l}\text { B cells (adherent to } \\
\text { nylon wool) }\end{array}$ & $\begin{array}{l}60-80 \% \text { uniformly, } \\
\text { densely labeled }\end{array}$ \\
\hline $\begin{array}{l}\text { A.TH anti-A.TL } \\
\text { anti-Ia } 1,2,3,7\end{array}$ & A.TL & $\begin{array}{l}1,2,3,7 \\
\mathrm{t} 1\end{array}$ & $\begin{array}{l}\text { Incubated with anti-la } \\
\text { at } 37^{\circ} \mathrm{C}\end{array}$ & $\begin{array}{l}\text { About } 40 \% \text { labeled } \\
\text { with capping }\end{array}$ \\
\hline $\begin{array}{l}\text { A.TL anti-A.TH } \\
\quad(\text { pool } 1) \\
\text { anti-la } 4,5,9\end{array}$ & A.TH & $\begin{array}{l}4,5,9 \\
\mathrm{t} 2\end{array}$ & None & Light label $10 \%$ of cells \\
\hline $\begin{array}{l}\text { A.TL anti-A.TH } \\
\text { (pool 2) }\end{array}$ & A.TH & $\begin{array}{l}4,5,9 \\
\mathrm{t} 2\end{array}$ & None & $\begin{array}{l}\text { About } 35 \% \text { of cells } \\
\text { heavily labeled and } \\
\text { capped }\end{array}$ \\
\hline $\begin{array}{l}\text { A.TL anti-A.TH } \\
\text { (pool 2) }\end{array}$ & A.TL & $\begin{array}{l}1,2,3,7 \\
\mathrm{t} 1\end{array}$ & None & No label \\
\hline $\begin{array}{l}\text { A.TL anti-A.TH } \\
\text { (pool 2) }\end{array}$ & B10.S & $\begin{array}{l}4,5,9 \\
s\end{array}$ & None & $\begin{array}{l}\text { About } 35 \% \text { labeled and } \\
\text { capped }\end{array}$ \\
\hline A.TH NS & A.TH & $\begin{array}{l}4,5,9 \\
\mathrm{t} 2\end{array}$ & None & No label \\
\hline A.TH NS & A.TL & $\begin{array}{l}1,2,3,7 \\
\mathrm{t} 1\end{array}$ & None & $\begin{array}{c}\text { Siparse label on less } \\
\text { than } 25 \% \text { of cells }\end{array}$ \\
\hline
\end{tabular}

"Ia specificities on top line, $\mathrm{H}-2$ haplotypes on second line.

${ }^{b} \mathrm{~L}, \mathrm{~N}=$ lymph node cells.

$\cdot \mathrm{NS}=$ normal serum.

In the cytotoxic test, A.TH anti- $\Lambda$.TL scrum reacts with cells of the AKR.M $\left(H-2^{\mathrm{m}}\right.$, Ia $\left.1,2,3,7\right)$ and B10.K $\left(H-2^{\mathrm{k}}\right.$, Ia $\left.1,2,3,7\right)$ strains, as well as with the A.TI. cells which elicited the immune response. These reactions were confirmed by our ferritin labeling study. Lymph node cells from B10.S and A.TH, which fail to react in the cytotoxic test, also failed to react with A.TH anti-A.TL serum in the ferritin labeling experiments. Labeling of B10.K cells was very strong and at least $60 \%$ of 

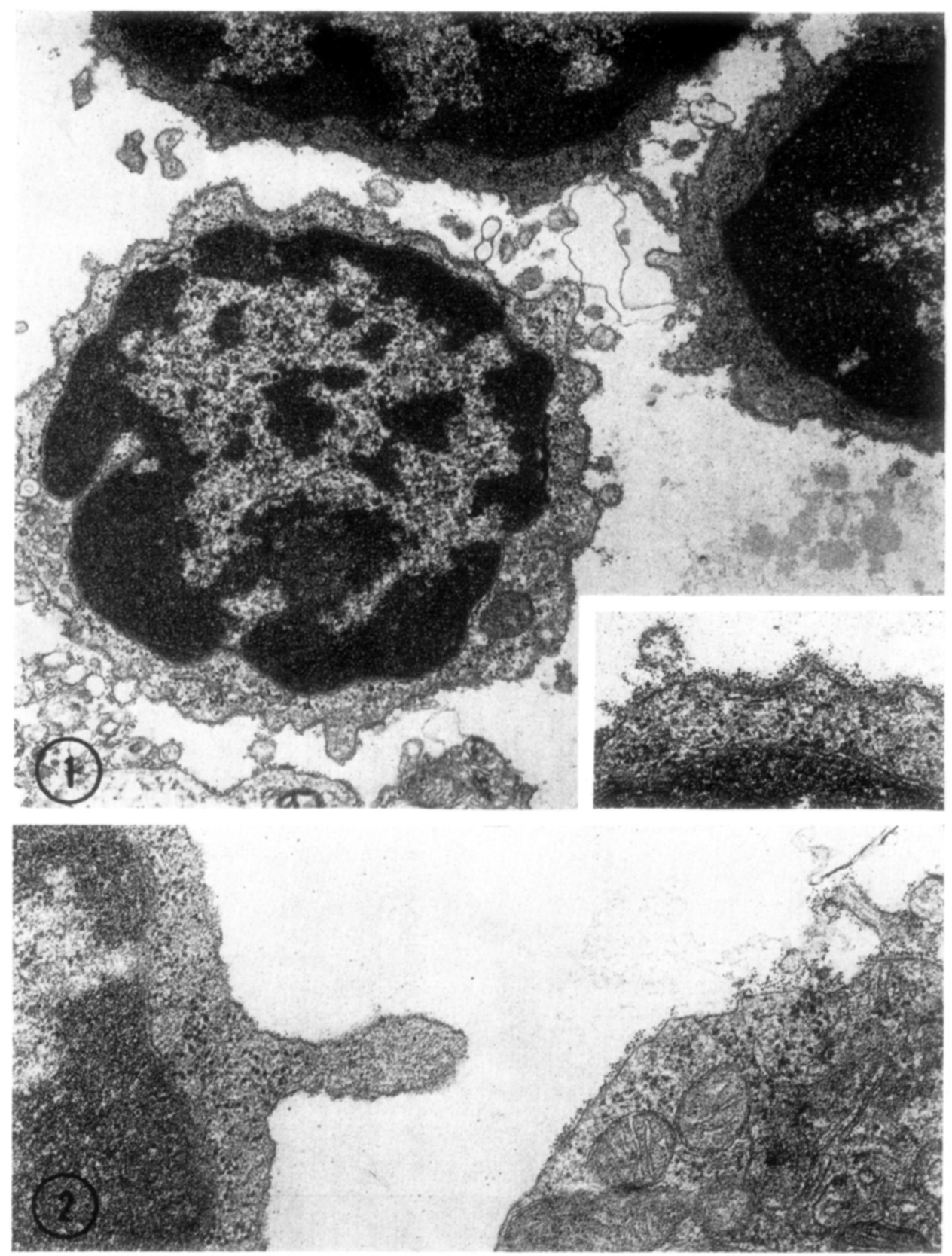

Fic. 1. A.TL cells incubated with A.TH anti-A.TL serum showing uniform distribution of ferritin label on the cell surface: $\times 19,000$. Inset shows the distribution of labeling at a high magnification: $\times 38,000$.

Fig. 2. A.TL cells incubated with A.TH normal serum. Almost all cells showed no label as in the cell on the left A few cells, however, showed scattered, sparse label as in the cell on the right. $\times 38,000$. 
cells were labeled. AKR.M cells were labeled but sparsely and nonuniformly, and $50 \%$ of all cells appeared to lack any label. In cases where large portions of the cell surface lack labeling. cells which react with the antibody may be overlooked if the cell, by chance, is sectioned through an unlabeled area. Thus it is possible that only $40 \%$ of cells of the AKR.M cell preparation appear to be labeled by immunoelectron microscopy, although $60 \%$ of AKR.M cells are killed in the cytotoxic test by this antiserum. Some labeled cells could easily be missed due to the chance plane of sectioning. The precise reacon that AKR.M cells should show patched labeling and lighter labeling under the same condition under which the other positive reactors show dense, evenly distributed labeling is still undetermined.

Only a small anount of nonmiform label was found on the B10.D2 cells incubated in A.TH anti-A.TL, serum. This limited, nonuniform labeling was unexpected, ats $H-2$ d strains react strongly with this anticerum in the cytotoxic test. Interestingly, these strains shared only Ia-7 with A.TL and B10.K. This is the only Ia specificity convincingly shown to be present on $T$ as well as $\mathrm{B}$ cells (15). Reactivity with $T$ cells is difficult to demonstrate in the cytotoxicity test, and it has been speculated that this might be due to a low density of antigenic sites on the T cells. The finding that B10.I)2 cells label sparsely lends further credence to this idea. It is also possible that the antigens of the $H_{-2}{ }^{4}$ and $H_{-2}{ }^{\mathrm{k}}$ strains which react with anti-la- $f$ are stufficiently different in binding efficiency so that the antibodies which hind tightly enough to react in the sensitive cytotoxic test were removed by repeater washings in these experiments.

In initial experiments, the reaction of A.TI, anti-A.TH serum with A.TH cells ( $H_{-2}{ }^{2 t h}$. Ia 4.5.9) showed only trace ferritin labeling with about $10 \%$ of cells labeling lightly. These results were puzzling in view of the strong cytotoxic reaction of this serum with these cells. When a second pool of antiserum was employed in a replicate incubation. however, about $40 \%$ of the cells showed a dense label but a considerable amount of capping ( see Fig. 3).

When A.TH anti-A.TL serum was reacted with A.TI, cells and both inculations performed at $37^{\circ} \mathrm{C}$. considerable capping was noted (Fig. 4). Fewer cells appeared to be labeled than in uncapped preparations as expected in capped preparations, due $t o$ the nonuniform distribution of sites in capped cells.

When lymph nole cells from an A.TI. mouse were fractionated on nylon wool columns into an adherent and nonadherent ( $T$ cell) population prior to incubation with A.TH anti-A.TI, serum, nonadherent cells were totally negative for ferritin labeling. Adherent cells, event though depleted by one-third by the removal of nonarlherent negative cells, were not enriched in number of cells labeled. with the level remaining at about $60 \%$ of the total cells in the adherent population. These results agreed exactly with cytotoxic tests employing the same antisera and cells fractionated in the same manner (15).

The specificity of our results with the A.TH anti-A.TI. serum wats confinned ly absorption studies. When spleens of $\mathrm{A}$. TI mice were used to absorls this antiserum, the supernatant showed less than $20 \%$ sparse labeling with $\mathrm{A}$.TI colls. This probably represents incomplete absorption. Sinilar results have been olsserved in cytotoxic tests, where it is difficult to obtain complete absorption without using high dilutions of antiserum (15). Absorption with A.TH spleen resulted in dense labeling of $50 \%$ witl, A.TI. cells, not a significant reduction over nuabsorbed serum. 


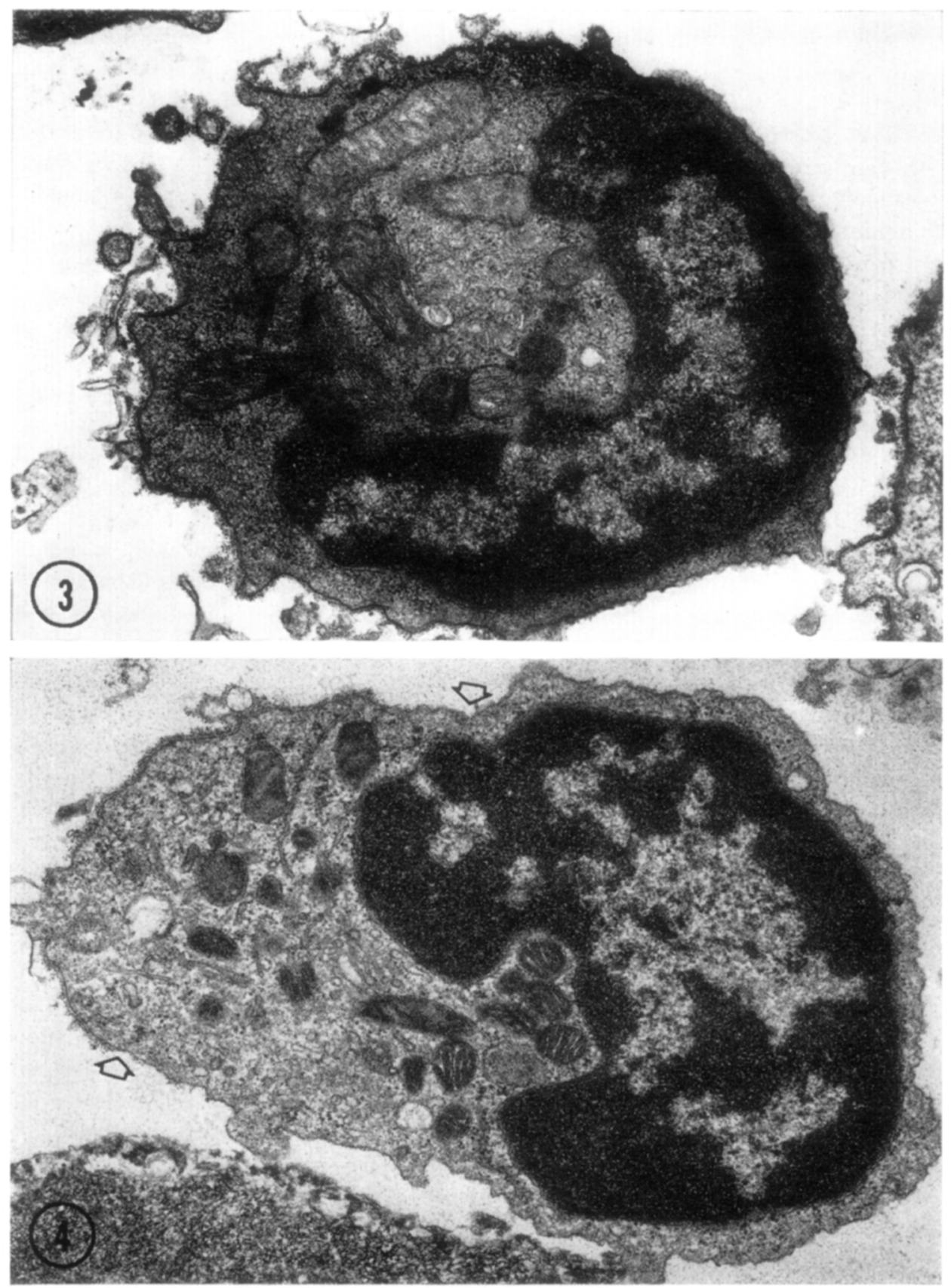

FIG. 3. A.TH cells incubated with A.TL anti-A.TH serum (pool 2). The first incubation was at $4^{\circ} \mathrm{C}$ and the second at $37^{\circ} \mathrm{C}$. Label was dense and localized on about $50 \%$ of the cell surface toward one pole. Cell projections were noted in the area of localization of label. $\times 31,350$.

FIG. 4. A.TL cells incubated with A.TH anti-A.TL serum. Both incubations were carried out at $37^{\circ} \mathrm{C}$. Label was localized at one pole of the cell ("capped") between two arrows. $\times 31,350$. 


\section{DISCUSSION}

In general, there is good agreement between the results obtained here with ferritin labeling and cytotoxic test in the specific strains reacting with a given reagent. A.TH anti-A.TL serum reacts quantitatively in the same manner with B10.K and A.TL cells as it does in the cytotoxic test. The antiserum labels AKR.M cells considerably less densely, with a patchy pattern of labeling on the cell surface and a slightly lower percentage of cells labeled.

Different capping conditions also seem to exist for A.TH anti-A.TL and A.TLL anti-A.TH sera, leading to a deceivingly low apparent labeling percentage for the latter antisera when compared with the percentage killed in the cytotoxic test. This antiserum appears to have different capping properties than those of the antithetical antiserum, but it is impossible at this time to deternine the etiology of this clifference.

The results of the test with nylon wool purified T and $B$ cells exactly duplicate results in the cytotoxic tests. The nonadherent population shows no significant lysis in the cytotoxic test. On the other hand, the adherent poptulation shows about the same percent cells lysed and labeled. This percentage is approximately the same as the percent lysed and labeled in the total sample. Apparently, some population of cells which carries Ia antigens is being destroyed by the separation process, is no longer expressing the antigen, or cannot be eluted from the column. Since there is convincing evidence that $T$ cells do possess Ia antigenic sites (15), these cells with altered behavior are probably a subpopulation of $\mathrm{T}$ cells.

Since recipient strain cells are always totally negative (clear of ferritin) in the labeling test, it is apparent that our wash procerlure is efficient and that the rablit anti-nouse IgG-ferritin conjugate is not reacting with surface inmunoglobulin. We may therefore conclude that the trace labelings with normal serum may be clue to naturally occurring antibodies in the recipient strain. These naturally occurring antibodies may explain high cytotoxic backgrounds found in certain serum cell combinations.

We recognize the fact that the percentages of cells which are labeled with ferritin when studied in the electron microscope are very rough approximations as it is difficult to count sufficient cells to refine these figures. However, it is clear that only a portion of the cells are labeled in any preparation. These cells which are labeled are strongly labeled while the negative cells in the same preparation are virtually free of any ferritin particles (see Fig. 1 and 2). The agreement between the approximate percent of reactive cells noted in the ferritin-labeled preparation and those lysed in the cytotoxic assay is quite striking for the antiserum, A.TH anti-A.TI.

The difference in labeling properties between A.TH anti-A.TI and the antithetical antiserum, A.TI, anti-A.TH, has been revealed by the ferritin labeling tests and nust now be elucidated. Such a difference cannot be letected in the cytotoxic assay and may reflect a difference in antigen mobilization properties, or variation in the heavy chain class of the antibodies involved.

It is clear from these experiments that $\mathrm{Ia}$ and $\mathrm{H}-2$ antigens have certain similarities. Both entities are expressed primarily on the cell surface and both can be capped ly the indirect antibody labeling technique. Capping conditions, density of sites on the cell surface, and populations of cell: carrying the antigens, however. differ between the two antigenic classes. Any further comparison is the sulject for a future study. 
The physiological significance of the Ia antigenic system has not as yet been determined. An intriguing possibility is that these antigens are related to systems controlling immune response in mice. Using the ferritin labeling technique described above, it will be possible to study the properties of these molecules, such as mobility on cell surfaces, distribution in cell populations, and relationship with other cell membrane structures, which cannot be determined by the techniques of the cytotoxic assay.

\section{ACKNOWLEDGMENTS}

The authors wish to acknowledge the excellent technical assistance of Virginia Hartog, and to thank Dr. Chella David for the two anti-Ia sera used. We would like, also, to thank Karen Dean for typing the manuscript. These are Veterans Administration Projects 7751:01 and 4927:01. This work was partially supported by USPHS Program Project Grant GM-15419 and USPHS Research Grant R01-AI-11962. One of the authors (J.A.F.) is a Jane Coffin Childs' Fellow, and another (D.C.S.) is the holder of USPHS Research Career Development Award K3-HL-24980.

\section{REFERENCES}

1. Klein, J., and Shreffler, D. C., Transplant. Rcv. 6, 3, 1971.

2. Aoki, T., Izard, J., Hammerling, U., de Harven, E., and Old, L. J., in "Proceedings of the 26th Annual Meeting, Electron Microscopy Society of America," p. 48. 1968.

3. Cerotini, J. C., and Brunner, R. T., Immunology 13, 395, 1967.

4. Aoki, T., Hammerling, U., de Harven, E., Boyse, E. A., and Old, L. J., J. Exp. Med. 130 , 979, 1969.

5. Kourilsky, F. M., Silvestre, D., Neauport-Sautes, C., Loosfelt, Y., and Dausset, J., Eur. J. Immunol. 2, 249, 1972.

6. Davis, W. C., Science 175, 1006, 1972.

7. Singer, S. J., and Nicolson, G. L., Science 175, 720, 1972.

8. De Petris, S., and Raff, M. C., Nature New Biol. 241, 257, 1973.

9. David, C. S., Shreffler, D. C., and Frelinger, J. A., Proc. Nat. Acad. Sci. U.S.A. 70, $2509,1973$.

10. Hauptfeld, V., Klein, D., and Klein, J., Science 181, 167, 1973.

11. Sachs, D. H., and Cone, J. L., J. Exp. Med. 138, 1289, 1973.

12. Hammerling, G. J., Deak, B. D., Mauve, G., Hammerling, U., and McDevitt, H. O., Immunogenetics $1,68,1974$.

13. Shreffler, D. C., David, C. S., Gotze, D., McDevitt, H. O., and Sachs, D., Immunogenctics $1,189,1974$.

14. David, D. S., and Shreffler, D. C., Transplantation 17, 462, 1974.

15. Frelinger, J. A., Niederhuber, J. E., David, C. S., and Shreffler, D. C. J. Exp. Med. 140, $1273,1974$.

16. Cullen, S. E., David, C. S., Shreffler, D. C., Nathensen, S. G., Proc. Nat. Acad. Sci. U.S.A. $71,648,1974$.

17. Shreffler, D. C., Amos, D. B., and Mark, R., Transplantation 4, 300, 1966.

18. Karnovsky, M. J., J. Cell Biol. 27, 137A, 1965.

19. Julius, M. H., Simpson, E., and Herzenberg, L. A., Eur. J. Immunol. 3, 645, 1973. 